ETO: $81 ’ 23$

ORIGINAL SCIENTIFIC PAPER

$81 ’ 373$

DOI: $10.19090 / \mathrm{hk} \cdot 2020.3 .1-12$

\title{
LENGYEL Zsolt
}

Pannon Egyetem

Veszprém, Magyarország

lengyelz@btk.uni-pannon.hu

\section{STRUKTURÁLÓDÁSI FOLYAMATOK A MENTÁLIS LEXIKONBAN}

\section{Structuring processes in the mental lexicon}

Procesi stvaranja strukture u mentalnom leksikonu

A tanulmány négy magyar nyelvü adatbázis anyagát elemzi az elsődleges válaszok szempontjából (ANYA-APA, ASZTAL-SZÉK, BETEGSÉG-EGÉSZSÉG stb.). Az adatfelvétel az 1980-as és 2000-es években történt 10-14, illetve 18-24 évesek körében. A vizsgált szavak közötti kapcsolatok erőssége nőtt: az elsődleges válaszok számaránya növekedett. Kulcsszavak: pszicholingvisztika, szóasszociáció, lexikai folyamatok

\section{A mentális lexikon strukturáltsága}

A tanulmány a magyar mentális lexikon strukturálódási folyamataira fókuszál a kronológiai változások tükrében. A mentális lexikon (agyi kollokációs szótár) strukturált jellegét az alábbi pszicholingvisztikai megfigyelések és az ezek nyomán kibontakozó kutatások támogatják, illetve igazolják.

\section{Szóbotlások}

Vannak „elfogadható”, azaz fáradtsággal, dekoncentrációval stb. magyarázható szóbotlások, pl. Vettél citromot, bocs narancsot? Ugyanakkor nem vagy alig tolerálható a Vettél citerát, bocs citromot? szócsere, pedig hangzásra a citrom és a citera közelebb áll egymáshoz, mint a citrom és a narancs. Tehát a lexikai elemek összetartozásában, strukturálódásában, szervezödésében a szemanti- 
ka fontosabb szerepet játszik, mint a fonetika/fonológia. A szervezettség más oldalát villantja fel az Éppen leszálltam a buszról, bocs a villamosról szóbotlás, amit inkább elfogadunk, mint az Éppen leszálltam a buszról, bocs a repülőröl szócserét, mivel a busz és a villamos a közlekedési eszközök szükebb csoportját alkotják, városi közlekedési eszközök, míg a busz és a repülö a közlekedési eszközökön belül távolabbi kapcsolatban vannak egymással.

\section{Szemantikai afázia}

A szemantikai afázia egyes esetei is azt erősítik, hogy bizonyos szócsoportok szorosabban kapcsolódnak egymáshoz. Előfordul olyan tünet, hogy a páciensnél kiesnek az állatok nevei, viszont meg tudja nevezni a hét napjait stb. A szókincs szerveződésében tehát jelen van a „kisvilágok” elv.

\section{Nyelvi ontogenezis (gyermeknyelv)}

A szervezettség és a strukturáltság mellett szólnak a nyelvfejlődés bizonyos jelenségei. A gyermeki szókincs kétéves korban még néhány szót tartalmaz, tehát elképzelhető ezek elemenkénti tárolása. De hároméves korban az értett és aktívan használt szavak száma már néhány ezret tesz ki, ezek tárolására, kezelésére nem megfelelő az elemenkénti. A gyermeki szókincs szerveződik, strukturálódik. A rendezettség kialakításában segítséget kap a gyerek, ennek egyik formája a prototípus kialakítása. Nem ritka dialógus gyermek és szülö között a következö: Ott egy cinke, de aranyos madár! De nehezen képzelhetö el az Ott egy tyúk, de aranyos madár! párbeszéd. A szülö tehát akaratlanul is kialakítja, hogy a magyar beszédközösségben a cinke tipikus madár. Rendelkezik a madár valamennyi kritériális jegyével: toll fedi, tojást költ, tud repülni. Bár a tyúk is madár, de annak egy tipikus jegye, a repülni tudás alig-alig jellemzi.

\section{Beszédértés, beszédprodukció}

A mentális lexikon strukturáltsága biztosítja a hétköznapi beszédértési és -produkciós múveletek gyorsaságát, pontosabban: ez a gyorsaság csak úgy lehetséges, ha rendezett struktúrák szolgálják ki.

\section{A mentális lexikon strukturáltságának vizsgálata}

Az alcímben megjelölt kérdés többféleképpen vizsgálható - többek között - szóasszociációs tesztelésekkel. Ezek közül jelen tanulmány az „egy hívószó 
(a továbbiakban HSZ, álló nagybetűvel) - egy válaszszó (a továbbiakban VSZ, dőlt kisbetüvel)" elrendezést alkalmazza. E technika szerint a tesztelteknek egy HSZ-t kínálnak, és a tesztalanynak az első eszébe jutó szóval kell válaszolnia. E módszer szerint négy magyar szóasszociációs adatbázis áll rendelkezésünkre: Balló Larissza 18-24 (1983), Jagusztinné Újvári Klára 10-14 (1985), Lengyel 10-14 (2008), illetve 18-24 (2010) éveseket tesztelt az említett módon. A négy vizsgálatban ugyanaz a 197 HSZ szerepelt. Mind a négy adatfelvétel írásban történt. A négy adatbázis egyfelől kronológiai (1980-as, illetve 2000-es évek), másfelől generációs (10-14, illetve 18-24 évesek) szempontok alapján különböznek. (Az adatbázisok digitalizált változatát lásd a Pannon Egyetem Magyar Nyelvtudományi és Alkalmazott Nyelvészeti Intézetének honlapján.)

\section{Kölcsönös behívások}

Az elemzendő szóasszociációs tesztekben bizonyos szavak HSZ-ként és VSZ-ként is előfordultak. Az alábbi táblázat ezek közül (csak a főnevekre vonatkozóan) azokat mutatja be, melyek egymást kölcsönösen az első helyen hívták be, és legalább 20 vagy afölötti százalékos értékben. A táblázat első oszlopa a HSZ-akat (ANYA, APA, ASZTAL stb.), második oszlopa a VSZ-akat (apa, anya, szék stb.) tartalmazza. A további oszlopok a négy tesztelt csoportban az összes válaszból az adott VSZ százalékos értékét tünteti fel (az ANYA HSZ az apa VSZ-t 13,84\%-os értékben váltja ki a 10-14: 80-as jelü csoportban stb.).

\begin{tabular}{llrrrr} 
& & $10-14: 80$ & $10-14: 20$ & $18-24: 80$ & $18-24: 20$ \\
\hline ANYA & apa & $13,84 \%$ & $34,03 \%$ & $11,69 \%$ & $40,97 \%$ \\
APA & anya & $18,24 \%$ & $32,10 \%$ & $21,30 \%$ & $45,81 \%$ \\
ASZTAL & szék & $20,75 \%$ & $24,05 \%$ & $28,83 \%$ & $32,96 \%$ \\
SZÉK & asztal & $17,61 \%$ & $25,84 \%$ & $21,67 \%$ & $30,17 \%$ \\
BETEGSÉG & egészség & $5,35 \%$ & $20,26 \%$ & $4,18 \%$ & $21,79 \%$ \\
EGÉSZSÉG & betegség & $16,67 \%$ & $23,61 \%$ & $23,32 \%$ & $20,67 \%$ \\
DOLOG & munka & $55,03 \%$ & $13,47 \%$ & $34,73 \%$ & $12,29 \%$ \\
MUNKA & dolog & $17,92 \%$ & $2,63 \%$ & $5,22 \%$ & $2,33 \%$ \\
KÉZ & láb & $14,15 \%$ & $20,11 \%$ & $12,07 \%$ & $17,32 \%$ \\
LÁB & kéz & $11,64 \%$ & $16,45 \%$ & $11,98 \%$ & $15,18 \%$
\end{tabular}


Az ANYA magasabb százalékos értékben hívja be az apa VSZ-t a 2000-es években, mint az 1980-asban mindkét generáció tekintetében. Hasonlót tapasztalunk az APA - anya, ASZTAL - szék, SZÉK - asztal, KÉZ - láb, LÁB - kéz párok esetében is. A kronológiai idő tehát növeli az elsődleges (leggyakoribb) válasz gyakoriságát. A jelenség ismert a nemzetközi szakirodalomban, a magyar szakirodalomban jelen tanulmány adatolja először. Taylor megjegyzése szerint: „Between 1910 and 1954, the response most frequently given by people, called the primary response, increased. For example, to table, the primary response chair was given by 26.7 percent of subjects in 1910; 33,8 percent in 1928; and 84.0 percent in 1954" (Taylor 1990, 171). A tendencia okainak feltárása még várat magára, többen az egyre erősödő, tömegesedő és hozzáférhető média hatásának tulajdonítják.

A fenti párok kölcsönösen, de nem szimmetrikusan hívják be egymást. Az APA rendszerint magasabb értékben váltja ki az anya VSZ-t, mint fordítva; az ASZTAL némileg nagyobb százalékos értékben a szék VSZ-t, mint fordítva. Feltűnően aszimmetrikus az EGÉSZSÉG és a betegség viszonya: az előbbi magas százalékos értékben csalja elő az utóbbit. Hasonló aszimmetria jellemzi a DOLOG és a MUNKA viszonyát; a DOLOG jóval magasabb százalékos értékben provokálja a munka VSZ-t, mint fordítva. Enyhe aszimmetrikus viszonyban van a KÉZ és a LÁB: a KÉZ valamivel nagyobb százalékos értékben hívja be a láb VSZ-t, mint a LÁB HSZ a kéz VSZ-t.

A fentebb szóba hozott aszimmetrikus viszonyok többnyire jól értelmezhetők. Enyhe aszimmetriát mutatott az ASZTAL és a SZÉK az ASZTAL javára. Ebben annak megnyilvánulását látjuk, hogy európai kultúrkörben együttes előfordulásuk gyakori, ezt tükrözi a kölcsönösség: ahol asztal van, ott rendszerint szék is van. Ám a szék állhat magában is (nézőtér, orvosi váró, egyetemi előadó stb.), az asztal kevésbé; ez látszik kifejeződni az enyhe aszimmetriában. A KÉZ és a LÁB viszonyában ugyancsak enyhe aszimmetria volt tapasztalható a LÁB szó javára, amely némileg alacsonyabb értékben hívta be a KÉZ szót. Bár az aszimmetriából fakadó dominancia csekély mérvü, de érdemes további etno- és/ vagy antropológiai nyelvészeti vizsgálatokat folytatni (van hegy lába, de nincs *hegy keze, van sors keze, de nincs * sors lába stb.). Erôsen aszimmetrikus az EGÉSZSÉG és a BETEGSÉG, illetve a MUNKA és a DOLOG viszonya. Az EGÉSZSÉG magasabb százalékos értékben hívja be VSZ-ként a betegség szót, mint fordítva. A viszony azt a valóságbeli helyzetet tükrözi, hogy a betegségnek sok fajtája van, így ezek is megjelennek VSZ-ként, és így „kevesebb hely” jut az egészség VSZ-nak. Az egészségnek nincsenek fajtái, így ellenkezőjének, a betegségnek több hely marad, azaz VSZ-ként magasabb százalékos értéket 
érhet el. Hasonló a MUNKA és a DOLOG szavak közti aszimmetrikus viszony magyarázata: munka sokféle lehet, de a dolog elsősorban fizikai tevékenység. Másként fogalmazva: minden dolog munka, de nem minden munka dolog. Az ANYA és APA viszonyát külön alpont elemzi.

\section{Az ANYA és az APA lingvisztikai és azon túli viszonya A viszony lingvisztikai aspektusa}

A fentebbi táblázat első két sora mutatta be a két szó kölcsönös behívási viszonyait.

$\begin{array}{lllll} & 10-14: 80 & 10-14: 20 & 18-24: 80 & 18-24: 20 \\ \text { ANYA - apa } & 13,84 \% & 34,03 \% & 11,69 \% & 40,97 \% \\ \text { APA - anya } & 18,24 \% & 32,10 \% & 21,30 \% & 45,81 \%\end{array}$

A két HSZ egymást hívja be első helyen, egymás leggyakoribb VSZ-ai; viszonyuk tehát kölcsönös. Látható azonban, hogy ez a kölcsönös viszony aszimmetrikus. Az APA HSZ többnyire magasabb százalékos értékben hívja be az anya VSZ-t, mint az ANYA HSZ az apa VSZ-t. Más szavakkal ez azt jelenti, hogy az APA HSZ kevesebb helyet biztosít az anya VSZ mellett más VSZ-aknak. Ugyanakkor mivel az ANYA HSZ-ra az apa VSZ alacsonyabb százalékos értékben jelenik meg, bőven van „hely” más VSZ-aknak. Nem lingvisztikai terminusokban ez azt jelenti, hogy az apa erösebben „rá van szorulva” az anyára, mint az anya az apára. A lingvisztikai mutatókon alapuló kölcsönös, de aszimmetrikus behívás különbségein túl egyéb eltérések is jelentkeznek az ANYA és az APA HSZ-ra adott VSZ-k között.

\section{Az ANYA és az APA mentális-verbális szófelhők szerinti profilja}

A mentális-verbális profilt a tanulmány úgy kívánja megrajzolni, hogy számba veszi az ANYA, illetve APA főnévi, melléknévi és igei VSZ-ai közül azokat, melyek legalább két válaszadótól származnak, és négy vagy három csoportban fordulnak elö. Így látjuk biztosítottnak, hogy az adott VSZ megjelenése nem a véletlennek tulajdonítható. A szófelhők szófajok szerint (főnévi, igei és melléknévi VSZ-ak) csoportosított formában szerepelnek az alábbi táblázatokban, különválasztva a négy és a három csoportban előfordulókat. A négy, illetve három csoportban való megjelenés szerinti megkülönböztetés azt szolgálja, hogy láthatóvá váljon HSZ és VSZ közötti szoros és kevésbé szoros kapcsolat. A négy csoportban közös VSZ az adott HSZ-hoz igen szorosan kötődik, míg 
a három csoportban szereplő VSZ kötődése bár szoros, de nem annyira, mint az elsőnek említetté. Míg a négy csoportban előforduló VSZ-ak az adott HSZ szoros értelemben vett szemantikai magját alkotják, addig a három csoportban szereplö VSZ-ak a szemantikai központ „külső körei”, de még nem szorulnak a perifériára. (A két és egy csoportban felbukkanó VSZ-ak jelen elemzésnek nem tárgyai, bár világos, hogy fontos információkat tartalmazhatnak a szemantikai magra és perifériára vonatkozóan.)

\section{ANYA, APA fönévi VSZ-ai}

Négy csoportban előforduló főnévi VSZ-ak (a két HSZ tekintetében közös VSZ-ak vastag szedéssel szerepelnek)

Az ANYA és APA jelzésü (1., 6.) oszlopokban (dőlt szedéssel) a VSZ-ak (ANYA - apa, szeretet stb.) láthatók. A 2., 3. stb. oszlopokban az egyes korcsoportok; a sorokban az adott VSZ százalékos aránya az összes VSZ-ból (az ANYA HSZ-ra apa VSZ-val élt az 1980-as 10-14 évesek 13,84\%-a stb.).

\begin{tabular}{|c|c|c|c|c|c|c|c|c|c|}
\hline ANYA & $\begin{array}{l}\text { 10-14: } \\
80\end{array}$ & $\begin{array}{l}10-14: \\
20\end{array}$ & $\begin{array}{l}\text { 18-24: } \\
80\end{array}$ & $\begin{array}{l}\text { 18-26: } \\
20\end{array}$ & APA & $\begin{array}{l}\text { 10-14: } \\
80\end{array}$ & $\begin{array}{l}10-14: \\
20\end{array}$ & $\begin{array}{l}\text { 18-24: } \\
80\end{array}$ & $\begin{array}{l}\text { 18-24: } \\
20\end{array}$ \\
\hline apa & 13,84 & 34,03 & 11,69 & 40,97 & anya & 18,24 & 32,10 & 21,30 & 45,81 \\
\hline szeretet & 10,06 & 14,18 & 14,81 & 11,73 & szz̈̈lö & 14,78 & 24,03 & 5,20 & 4,19 \\
\hline szüllö & 12,58 & 16,07 & 4,68 & 0,84 & család & 0,94 & 6,59 & 2,86 & 4,66 \\
\hline gyerek & 4,72 & 1,13 & 10,65 & 3,72 & szeretet & 3,14 & 5,29 & 3,64 & 2,79 \\
\hline anyukám & 6,29 & 0,19 & 4,16 & 1,12 & férfi & 5,66 & 1,95 & 2,86 & 1,86 \\
\hline lánya & 1,57 & 1,04 & 1,30 & 5,59 & fiú & 1,26 & 0,83 & 3,90 & 4,28 \\
\hline nö & 2,52 & 0,47 & 0,78 & 0,28 & fia & 2,52 & 0,74 & 5,20 & 1,86 \\
\hline \multirow[t]{3}{*}{ asszony } & 1,26 & 0,19 & 0,52 & 0,19 & férj & 0,94 & 0,19 & 1,04 & 0,09 \\
\hline & & & & & szigor & 0,31 & 0,19 & 1,04 & 1,30 \\
\hline & & & & & lánya & 0,31 & 0,09 & 0,26 & 0,38 \\
\hline
\end{tabular}

A négy csoportban előforduló VSZ-ak az alábbi alcsoportokra oszthatók:

- Az ANYA és az APA kölcsönösen egymást hívják be első (leggyakoribb) válaszként. A kölcsönös behívást az ezt megalapozó és lehetővé tevő nyelvilogikai müvelet könnyedsége magyarázza. Hogy az ANYA, illetve APA HSZ-ra az apa, illetve anya VSZ jelenjen meg, a két szó közös szemantikai jegygyüjteményéből az egyik jegy előjelét kell megváltoztatni. A behívás erőssége generációsan alig változik; a generációs különbségek nem túl nagyok: 
13,84 vs. 11,$69 ; 34,03$ vs. 40,$97 ; 18,24$ vs. 21,$30 ; 32,10$ vs. 45,81 . A kronológiai különbségek már jelentősebbek: 13,84 vs. 34,$03 ; 11,69$ vs. 40,97; 18,24 vs. 32,$10 ; 21,30$ vs. 45,81 . Arról fentebb esett szó, hogy az első leggyakoribb VSZ számaránya az idő elörehaladtával növekszik.

- Két VSZ - szeretet, szülö - mind az ANYA, mind az APA esetében megjelenik. A szülő egy magasabb („,fölöttes”) nyelvi-fogalmi szint lexémája, megjelenését az anya, illetve apa szavak egyik szemantikai jegyének elvétele eredményezi. A szeretet VSZ megjelenését nem lingvisztikai okok váltják ki, hanem a magyar (európai) beszédközösség társadalmi „vélekedése”.

- A további VSZ-ak tekintetében az ANYA, illetve APA HSZ részben azonos, részben eltérö. Azonosságnak tekinthetö, hogy az ANYA szóban forgó VSZ-ai tipikusan a „nőiesség”, ,anyaság” jegyeket mutatják fel (gyerek, anyukám, lánya, nö, asszony). Az APA VSZ-ainak egy része (a többség) szintén a nemiségre és az ennek megfelelő társadalmi funkciókra („,érfiasság”, ,,apaság”) fókuszál (család, férj, férfi, fiú, fia, lánya). Ez jelenti az azonosságot. A különbség az, hogy az APA HSZ-ra adott (mind a négy csoportban megjelenő) szigor VSZ a fenti szemantikai határokat átlépi, minősítést, értékelést fejez ki.

\section{Három csoportban előforduló főnévi VSZ-ak}

\begin{tabular}{|c|c|c|c|c|c|c|c|c|c|}
\hline ANYA & $\begin{array}{l}10-14: \\
80\end{array}$ & $\begin{array}{l}10-14: \\
20\end{array}$ & $\begin{array}{l}18-24: \\
80\end{array}$ & $\begin{array}{l}18-24: \\
20\end{array}$ & APA & $\begin{array}{l}10-14: \\
80\end{array}$ & $\begin{array}{l}10-14: \\
20\end{array}$ & $\begin{array}{l}\text { 18-24: } \\
80\end{array}$ & $\begin{array}{l}18-24: \\
20\end{array}$ \\
\hline család & 0 & 2,93 & 1,30 & 1,86 & családfö & 5,03 & 1,02 & 1,30 & 0 \\
\hline $\begin{array}{l}\text { gondos- } \\
\text { kodás }\end{array}$ & 0,94 & 1,51 & 0 & 1,58 & gyerek & 2,52 & 0 & 1,56 & 1,40 \\
\hline mama & 2,83 & 0,19 & 0 & 0,37 & fater & 1,89 & 1,02 & 0 & 0,09 \\
\hline jóság & 0,63 & 0 & 1,30 & 0,28 & munka & 0,94 & 1,02 & 0 & 0,65 \\
\hline muter & 1,26 & 0,38 & 0 & 0,37 & otthon & 0,31 & 0 & 2,08 & 0,37 \\
\hline melegség & 0,63 & 0 & 0,52 & 0,37 & bajusz & 0,28 & 0,52 & 0,84 & 0 \\
\hline leány & 0,63 & 0,47 & 0 & 1,68 & családtag & 0,31 & 0,46 & 0 & 0,19 \\
\hline fiú & 0,63 & 0,19 & 0 & 0,47 & erö & 0,63 & 0 & 0,26 & 0,28 \\
\hline fia & 0,63 & 0,57 & 0 & 0,19 & biztonság & 0 & 0,37 & 0,26 & 0,84 \\
\hline \multirow[t]{4}{*}{ anyatej } & 0 & 0,28 & 0,78 & 0,56 & jóság & 0,31 & 0,09 & 0,78 & 0 \\
\hline & & & & & ember & 0,31 & 0,93 & 0 & 0,37 \\
\hline & & & & & halál & 0 & 0,09 & 0,52 & 0,37 \\
\hline & & & & & papa & 0 & 0,09 & 0,52 & 0,19 \\
\hline
\end{tabular}


A három csoportban előforduló VSZ-ak az ANYA és APA HSZ-ak szemantikai központjának távolabbi rétegeihez tartoznak, de még nem periferikusak.

- A VSZ-ak legnépesebb csoportja az ,anyaság” és az ,apaság” inherens jegyeit jelenítik meg, olykor emocionálisan telítetten. Az ANYA HSZ kapcsán: jóság, melegség, gondoskodás VSZ-ak, az APA HSZ tekintetében az erő, biztonság, jóság, otthon VSZ-ak. Érzelmi töltet nélküli inherens sajátosságot tükröz az anyatej, illetve a bajusz. Nyelvi-fogalmi szintváltás eredményei az ANYA HSZ-val kapcsolatban a család, mama, illetve az APA vonatkozásában a gyerek, papa, ember VSZ-ak.

- „Kamaszos” (inkább a 10-14 évesek körében fordul elő), korosztályos (tehát erősen átmeneti) nyelvhasználati reakció: muter és fater.

- Vannak olyan VSZ-ak, melyek bár három csoportban jelennek meg az ANYA és APA HSZ-akra, de nem sorolhatók (szemben a fentiekkel) közös osztályba.

- Az ANYA HSZ-ra megjelennek a „nőiesség”, ,,anyaság” jegyekre fókuszáló VSZ-ak, melyeket egy adott jegy előjelének megváltoztatása eredményezi: fiú, fia.

- Csak az APA HSZ vált ki családi státuszra utaló VSZ-akat: családfo,, férj, családtag.

- Ugyancsak az APA HSZ-ra jelentkeznek a munka és a halál VSZ-ak. Az első alighanem azt az általános társadalmi vélekedést tükrözi, amely szerint az apa otthonról távozva munkába megy, míg az otthon maradó anya „nem dolgozik”. A halál VSZ magyarázata nehezebb. Talán azt az általános (és sajnálatos) tényt tükrözi, hogy a férfiak várható élettartama többnyire rövidebb, és a válaszadók közt több olyan személy is van, akinek az apja már nem él.

$$
\text { ANYA, APA igei VSZ-ai }
$$

Négy csoportban előforduló VSZ-ak (a két HSZ tekintetében közös VSZ-ak vastag szedéssel szerepelnek)

$\begin{array}{lllllllllll}\text { ANYA } & 10-14: & 10-14: & 18-24: & 18-24: & \text { APA } & 10-14: & 10-14: & 18-24: & 18-24: \\ & 80 & 20 & 80 & 20 & & & 80 & 80 & 20 \\ \text { szeret } & 3,77 & 1,13 & 2,08 & 1,40 & \text { szeret } & 0,94 & 0,19 & 0,78 & 0,09 \\ & & & & & \text { nincs } & 0,94 & 0,19 & 1,30 & 0,28 \\ & & & & & \text { szeretem } & 0,63 & 0,74 & 1,04 & 0,37 \\ & & & & & & \text { dolgozik } & 0,31 & 0,09 & 1,04 & 0,28\end{array}$


Az, hogy kevesebb igei, mint fönévi VSZ érkezik az ANYA, APA HSZ-akra, megegyezik a szóasszociációs teszteknek azzal a magyar és nemzetközi tanulságával, hogy a főnevek inkább paradigmatikus (szófajmegőrző), az igék és a melléknevek viszont inkább szintagmatikus (szófajváltó) válaszokat generálnak. A négy csoport egyetlen közös VSZ-a az ANYA és az APA HSZ-ak tekintetében a szeret, ami megfelel mind a lingvisztikai, mind „egyéb” elvárásainknak („egyéb” elvárásaink teszik érthetővé és elfogadhatóvá, hogy az ANYA HSZ valamennyi csoportban magasabb százalékos értékben váltja ki a szeret VSZ-t, mint az APA HSZ). Annak nem nyelvtudományi vagy pszicholingvisztikai magyarázata van, hogy az APA HSZ mentális-lingvisztikai profilja miért gazdagabb, a több VSZ következtében részletezöbb, mint az ANYA HSZ az igei VSZ-ak vonatkozásában. Az APA HSZ-ra a nincs VSZ mind a négy csoportban megjelenik, megerösítvén a halál VSZ-nál tett megjegyzést.

\section{Három csoportban előforduló VSZ-ak}

$\begin{array}{llllllllll}\text { ANYA } & 10-14: & 10-14: & 18-24: & 18-24: & \text { APA } & 10-14: & 10-14: & 18-24: & 18-24: \\ & 80 & 20 & 80 & 20 & & 80 & 20 & 80 & 20 \\ \text { szeretem } & 0,47 \% & 0,78 \% & & 0,84 \% & & & & & \end{array}$

Az ANYA HSZ-ra jelenik meg három csoportban a szeretem VSZ, amely érdekes és lingvisztikailag nem magyarázható módon - az APA HSZ-nál mind a négy csoportban jelen van.

\section{ANYA, APA melléknévi VSZ-ai}

Négy csoportban előforduló melléknévi VSZ-ak (a két HSZ tekintetében közös VSZ-ak vastagon szedve)

\begin{tabular}{|c|c|c|c|c|c|c|c|c|c|}
\hline ANYA & $\begin{array}{l}10-14: \\
80\end{array}$ & $\begin{array}{l}10-14: \\
20\end{array}$ & $\begin{array}{l}\text { 18-24: } \\
80\end{array}$ & $\begin{array}{l}\text { 18-24: } \\
20\end{array}$ & APA & $\begin{array}{l}\text { 10-14: } \\
80\end{array}$ & $\begin{array}{l}10-14: \\
20\end{array}$ & $\begin{array}{l}\text { 18-24: } \\
80\end{array}$ & $\begin{array}{l}18-24: \\
20\end{array}$ \\
\hline jó & 5,66 & 0,66 & 1,30 & 0,56 & jó & 1,57 & 0,28 & 2,34 & 0,28 \\
\hline \multirow[t]{3}{*}{ kedves } & 1,89 & 0,66 & 1,82 & 0,56 & kedves & 0,94 & 1,02 & 1,04 & 0,37 \\
\hline & & & & & szigorú & 0,63 & 0,19 & 3,64 & 0,19 \\
\hline & & & & & rossz & 0,31 & 0,09 & 0,26 & 0,09 \\
\hline
\end{tabular}

Az ANYA és az APA HSZ-ra a - főnévi asszociátumok számával egybevetve - szerényebb számú melléknévi VSZ megerősíti a fentebb mondottakat: a főnévi HSZ-ak elsődlegesen paradigmatikus és kevesebb szintagmatikus választ provokálnak. 
A két vizsgált HSZ mind a négy csoportban előcsalja a jó és kedves válaszokat, ami elvárásunknak megfelel. Az APA HSZ (akárcsak az igéknél) több melléknévi VSZ-t generál, közte olyanokat is (rossz), melyek figyelmeztetőek (nem lingvisztikai szempontból).

\section{Három csoportban előforduló melléknévi VSZ-ak}

$\begin{array}{llllllllll}\text { ANYA } & 10-14: & 10-14: & 18-24: & 18-24: & \text { APA } & 10-14: & 10-14: & 18-24: & 18-24: \\ & 80 & 20 & 80 & 20 & & 80 & 20 & 80 & 20 \\ \text { édes } & 3,46 \% & 0 & 10,13 \% & 0,56 \% & \text { édes } & 6,92 \% & 0 & 6,49 \% & 1,02 \% \\ & & & & & \text { magas } & 0 & 0,28 \% & 0,26 \% & 0,37 \%\end{array}$

A három csoportban közös VSZ-ak közül az édes mind az ANYA, mind az APA HSZ kapcsán megjelenik (édesanya, édesapa), ami magyar beszédközösségi sajátosság. Az APA nem szükebb központi szemantikai szférájához tartozik a külsőre való utalás (magas), az ANYA ezt az eljárást nélkülözi.

\section{Összegzés}

\section{A strukturálódási folyamatok realitása}

A lexikai elemek strukturálódási folyamatait, azaz a szavak közötti rendszerszerủ kapcsolat valós voltát a fenti empirikus adatok igazolták. Különösen erős bizonyítékot szolgáltattak ebben a tekintetben azok a szavak, amelyek között kölcsönös behívási viszony alakult ki, illetve szilárdult meg. A magyar tesztanyagban (a nemzetközi tendenciával megegyezö módon) tetten érhetö volt, hogy e kapcsolatok az idő során erősödnek, ami abban a formában jelentkezett, hogy a leggyakoribb (elsődleges) válasz százalékos értéke növekedett a 2000-es években az 1980-as időponthoz képest. A növekedés okai további vizsgálatokat igényelnek.

\section{Szimmetrikus és aszimmetrikus kölcsönösség}

Voltak majdnem szimmetrikus (igen enyhe aszimmetriát felmutató) és erőteljesen aszimmetrikus párok. A kapcsolatok ilyen vagy olyan formájú kialakulása, megszilárdulása aláhúzza annak fontosságát, hogy az anyanyelv elsajátításának folyamata nem zárul le a korai gyermekévekben, hanem más formát ölt. A korai gyermekéveket a lexikai elemek (szavak) nagy tömegü és rapid birtokbavétele jellemzi. A későbbi (kiskamasz és fiatal felnőttkori) szakaszban a birtokolt lexikai elemek elrendezésének, egymásra vonatkoztatásának, kapcsolatba hozásának feladatával kell megbirkózni. Más szavakkal: lexikai hálózatokat 
kell építeni. A hálózatépítés folyamatát részben saját megfigyelések tanulságai, részben társadalmi tapasztalatok átvétele segíti. (Az iskoláztatás egyik fontos feladata a hálózatépítés segítése.)

- A kapcsolatépítés egyfelől a környezeti tárgyi feltételének megfigyelését, elemzését igényli. Erre szolgált példaként az asztal és a szék viszonya. A kölcsönösség mellett enyhe aszimmetria mutatkozott a szék javára, ami úgy magyarázható és értelmezhető, hogy az európai (és a magyar) kultúrkörben együttes előfordulásuk gyakori, ám a szék állhat magában is, az asztal kevésbé.

- Etnolingvisztikai vizsgálatokat igényel, hogy a magyar beszédközösségben a KÉZ és a LÁB enyhe aszimmetrikus viszonyban van.

- Erősen aszimmetrikus viszonyban van az EGÉSZSÉG és a BETEGSÉG, illetve a MUNKA és a DOLOG, tükrözvén azt a helyzetet, hogy a betegségnek sok, az egészségnek viszont nincsenek fajtái, ezért az egészség erősebben kapcsolódik a betegséghez, míg a betegség lazábban az egészséghez. Hasonlóan: a munka sokféle lehet, de a dolog elsősorban fizikai tevéken ség; minden dolog munka, de nem minden munka dolog. Ez a példa arra is felhívja a figyelmet, hogy a nyelvelsajátítás nem pusztán adott jelrendszer birtokbavétele, hanem adott beszédközösség világlátásának elsajátítása is.

\section{ANYA éS APA}

Az ANYA és az APA szavak viszonya egyfelől kölcsönös (egymást hívják be első helyen), másfelől aszimmetrikus (az ANYA dominál). Kapcsolatuk az idő előrehaladtával erősödik. A mentális-verbális profi vizsgálata, azaz a főnévi, melléknévi és igei VSZ-ak számbavétele az alábbi tanulságokkal szolgált:

- Az anya és az apa szoros kapcsolatára utalnak a közös VSZ-ak: szeretet, szülö.

- Összetartozásuk jeleként könyvelhetőek el az egymást feltételező, kiegészítő, de ellentétes irányba mutató VSZ-ak, melyek a „nőiesség”, ,anyaság” (gyerek, anyukám, lánya, nö, asszony), illetve a ,férfiasság”, ,,apaság” (család, férj, férfi, fiú, fia, lánya) jegyeket hozzák a fókuszba.

- További (nem feltétlenül lingvisztikai) vizsgálat adhat választ markánsan jelentkező különbségekre. Az APA HSZ mentális-lingvisztikai profilja gazdagabb (részletezőbb), ami abban jutott kifejezésre, hogy érzékelhetően több igei és melléknévi VSZ-t provokált az APA HSZ, mint az ANYA HSZ. Érdemes azt is kiemelni, hogy a nincs és a halál VSZ-ak csak az APA HSZ-ra jelennek meg. 


\section{Irodalom}

Kovács László. 2011. Fogalmi rendszerek és lexikai hálózatok a mentális lexikonban. Budapest: Tinta Könyvkiadó.

Lengyel Zsolt. 2012. Szóról szóra: Szóasszociációs vizsgálatok. Budapest: Gondolat Kiadó.

Taylor, Insup. 1990. Psycholingustics. Learning and Using Language. Englewood Cliffs, New Jersey: Prentice Hall.

\section{STRUCTURING PROCESSES IN THE MENTAL LEXICON}

The study analyzes the material of four Hungarian language databases in terms of primary answers (MOTHER-FATHER, TABLE-CHAIR, SICKNESS-HEALTH etc.). Data collection took place in the 1980s and 2000s among 10-14 and 18-24 year olds, respectively. The primary response has increased. For example, the primary response to TABLE was 21,67 percent in 1980 which has increased to 30,17 percent in 2010. Keywords: psycholinguistics, word association, lexical processes

\section{PROCESI STVARANJA STRUKTURE U MENTALNOM LEKSIKONU}

Studija analizira primarne reakcije (ANYA - APA, ASZTAL - SZÉK, BETEGSÉG - EGÉSZSÉG, tj. MAJKA - OTAC, STO - STOLICA, BOLEST - ZDRAVLJE i sl.) u četiri baze podataka na mađarskom jeziku. Prikupljanje korpusa je obavljeno između 1980. i 2000. godine među mladima uzrasta između 10-14 i 18-24 godine. Čvrstina veze između analiziranih reči se povećavala: brojčana srazmera primarne reakcije je rasla.

Ključne reči: psiholingvistika, leksičke asocijacije, leksički procesi 